\title{
SPATIAL AND TEMPORAL HYDROCHEMICAL VARIATIONS OF THE SPRING-FED TRAVERTINE-DEPOSITING STREAM IN THE HUANGLONG RAVINE, SICHUAN, SW CHINA
}

\author{
PROSTORSKE IN ČASOVNE HIDROKEMIČNE SPREMEMBE \\ LEHNJAKOTVORNEGA VODOTOKA V SOTESKI HUANGLONG, \\ PROVINCA SICHUAN, JZ KITAJSKA
}

\author{
Haijing WANG ${ }^{1}$, Zaihua $\mathrm{LIU}^{1,2}$, Jinliu ZHANG ${ }^{1}$, Hailong $\mathrm{SUN}^{1}$, Dejun $\mathrm{AN}^{3}$, Ruxian $\mathrm{FU}^{3}$ \& Xiaoping WANG
}

\begin{abstract}
UDC 556.34:54(510)

Haijing Wang, Zaihua Liu, Jinliu Zhang, Hailong Sun, Dejun An, Ruxian Fu \& Xiaoping Wang: Spatial and temporal hydrochemical variations of the spring-fed travertine-depositing stream in the Huanglong Ravine, Sichuan, SW China

Automatic hydrochemical logging and in situ titration combined with laboratory analysis were used to understand the spatial and temporal hydrochemical variations of the springfed, travertine-depositing stream in celebrated Huanglong Ravine, Sichuan, SW China. This is essential for protection of the Huanglong World Natural Heritage travertine landscape. It was found that the deposition of travertine was due to very strong $\mathrm{CO}_{2}$ degassing from the water, leading to decrease in $\mathrm{pCO}_{2}$ and specific conductivity $(\mathrm{SpC})$, and increase in $\mathrm{pH}$ and SIc downstream from the Spring. However, regular downstream hydrochemical evolution was interrupted by dilution with snow-melt water and by renewed $\mathrm{CO}_{2}$ from some downstream springs. The chemistry of Huanglong Spring itself was stable at a diurnal scale though it was altered by the great Wenchuan earthquake of May 12 2008. However, in spring-fed pools downstream, $\mathrm{pCO}_{2}$ and $\mathrm{SpC}$ were lower, and $\mathrm{pH}$ and SIc were higher in daytime than at night, which indicates that the deposition of travertine was faster during the daylight hours. This was due to the combined effects of higher water temperatures and higher aquatic algae photosynthesis. In addition, it was found that the phosphate concentration in the stream increased remarkably downstream in the tourist midseason, indicating water pollution by tourism activities. The increase of phosphate (an inhibitor of calcite precipitation) may be one of the reasons for the decrease in travertine deposition rates and accelerated propagation of discoloration by diatoms during the past decades, which needs to be given more comprehensive study and tackled in future for the protection of these world famous travertine deposits.

Keywords: hydrochemical variation, $\mathrm{CO}_{2}$-degassing, aquatic photosynthesis, dilution effect, phosphate pollution, Huanglong travertine.
\end{abstract}

Povzetek UDK 556.34:54(510)

Haijing Wang, Zaihua Liu, Jinliu Zhang, Hailong Sun, Dejun An, Ruxian Fu \& Xiaoping Wang: Prostorske in časovne hidrokemične spremembe lehnjakotvornega vodotoka $v$ soteski Huanglong, provinca Sichuan, JZ Kitajska

Metode avtomatskega hidrokemičnega merjenja in beleženja ter in situ titriranja skupaj $\mathrm{z}$ laboratorijskimi analizami so bile uporabljene, da bi razumeli prostorske in časovne hidrokemične spremembe vodotoka, ki ga napaja izvir Huanglong in ki v soteski Huanglong v kitajski provinci Sichuan odlaga lehnjak. Zaščita odlaganja lehnjaka je ključna za obstoj lehnjakove pokrajine Huanglong, ki je območje svetovne naravne dediščine. Ugotovljeno je bilo, da do odlaganja lehnjaka prihaja zaradi silnega sproščanja $\mathrm{CO}_{2}$ iz vode, kar vodi do upada $\mathrm{pCO}_{2}$ in prevodnosti ter porasta $\mathrm{pH}$ in SIc vrednosti dolvodno od izvira Huanglong. Hidrokemični razvoj je dolvodno prekinjen zaradi redčenja $\mathrm{z}$ vodo iz talečega snega ter s pritoki nižje ležečih izvirov. Po drugi strani pa so kemične značilnosti izvira Huanglong na osnovi vsakodnevnih vrednosti stabilne. Te vrednosti pa so bile spremenjene ob velikem potresu v Wenchuanu 12. maja 2008. Vendar so bile v jezerih, ki jih napajajo izviri, podnevi izmerjene nižje vrednosti $\mathrm{pCO}_{2}$ in prevodnosti ter višje vrednosti pH in SIc kot ponoči. To kaže, da je podnevi izločanje lehnjaka hitrejše kot ponoči. Ugotovljeno je bilo, da je vzrok za to kombinacija višjih dnevnih temperatur in večje fotosinteze vodnih alg podnevi. Ugotovljeno je bilo tudi, da so se koncentracije fosfatov dolvodno $\mathrm{v}$ soteski Huanglong izredno povišale $\mathrm{v}$ času turistične sezone. To kaže na obstoj onesnaževanja voda s strani turističnih aktivnosti. Porast koncentracije fosfatov je lahko eden od vzrokov za zmanjšanje odlaganja lehnjaka $\mathrm{v}$ zadnjih desetletjih. V prihodnosti je potrebno posvetiti več pozornosti ter obsežne raziskave zaščiti lehnjakove pokrajine.

Ključne besede: hidrokemične spremembe, sproščanje $\mathrm{CO}_{2}$, fotosinteza vodnih alg, učinek redčenja, onesnaženje s fosfati, lehnjak Huanhlong.

\footnotetext{
${ }^{1}$ State Key Laboratory of Environmental Geochemistry, Institute of Geochemistry, CAS, Guiyang 550002, China, e-mail: liuzaihua@vip.gyig.ac.cn

${ }^{2}$ Karst Dynamics Laboratory, MLR, Institute of Karst Geology, CAGS, Guilin 541004, China

${ }^{3}$ Huanglong National Scenic Spot Administration, Songpan 623300, China

Received/Prejeto: 10.12 .2009
} 


\section{INTRODUCTION}

Travertine or tufa is a freshwater carbonate that is deposited in open-air conditions in limestone and dolomite areas. Typically it is a chemical sedimentary deposit formed from spring-fed stream waters rich in dissolved carbon dioxide and calcium bicarbonate (Ford \& Pedley 1996). It is found in many karst regions of the world, where it can form spectacular terraces, cascades and dams (Emeis et al. 1987; Liu et al. 1995; Pentecost 1995; Ford \& Pedley 1996). The chemical changes that take place once travertine depositing spring waters emerge in the open air are well understood (Emeis et al. 1987; Herman \& Lorah 1987; Dreybrodt et al. 1992; Liu et al. 1995; Liu et al. 2003). Before any carbonate is deposited, the waters lose $\mathrm{CO}_{2}$ as they equilibrate with ambient atmospheric conditions, which results in them becoming supersaturated with respect to the dissolved carbonate minerals. Carbonate deposition, usually as calcite, occurs once kinetic thresholds to mineral formation are overcome (Ford \& Williams 2007). Consequently, the point at which deposition commences is often located in stream channels well downstream of spring orifices, and deposition may continue for a few kilometers thereafter (Liu et al. 1995). The hydrochemical evolution is also controlled by the physicochemical adjustment of the solution as it interacts with streambed geomorphology. Abrupt changes in stream longitudinal profile enhance $\mathrm{CO}_{2}$ degassing, whilst in slowing moving zones (e.g., in travertine pools) it is considerably retarded (Liu et al. 1995). For a solution with given $\mathrm{CO}_{2}$ and $\mathrm{Ca}^{2+}$ concentrations, this solutionbed interaction governs precipitation kinetics, which not only control where deposition may occur, but also the rate at which the calcite is precipitated (Liu et al. 1995; Dreybrodt et al. 1997). At the solution-mineral interface there is also strong evidence that biogenic factors may be significant in travertine deposition (Emeis et al. 1987; Pentecost 1998; Plenkovic-Moraj et al. 2002), especially in standing water where $\mathrm{CO}_{2}$ removal by biogenic activity may be of equal or greater importance than removal by physicochemical means. Thus, travertine forming in lakes and low-velocity reaches of stream systems may display strong biogenic influences (Pedley 2000).

In recent years, travertine research has focused on refining our knowledge of specific depositional processes, particularly with respect to stream chemistry. For example, links between seasonal climate, groundwater discharge, spring water concentrations and changes in the longitudinal distribution of travertine deposition have been investigated for river systems (Drysdale et al. 2002). Drysdale et al. (2003) also investigated the influence of diurnal temperatures on the hydrochemistry of a tufa-depositing stream in central NSW, Australia. Results showed that changes in the amount of $\mathrm{CaCO}_{3}$ deposited upstream of the study reach were directly related to changes in diurnal water temperatures, which control the rate of $\mathrm{CO}_{2}$ degassing to the atmosphere.

Many scholars have also studied the Huanglong travertine-depositing stream. Lu \& Li (1992) demonstrated the inter-dependence between slope travertine, pool travertine, and waterfall travertine deposits. Lu (1994) and $\mathrm{Lu}$ et al. (2000) discussed the downstream evolution of hydrochemistry along the flow path, and the influence of hydrodynamics on $\mathrm{CO}_{2}$ out-gassing and $\mathrm{CaCO}_{3}$ precipitation. Liu et al. (1995) predicted $\mathrm{CaCO}_{3}$ precipitation rates from the aqueous chemistry in the faster flowing waters. However, these researches did not further distinguish the roles of other possible factors such as aquatic organisms in controlling the travertine deposition. In addition, much work remains to be done to protect the travertines in the face of ever increasing tourism activities. For instance, very little is known about the temporal variations of the hydrochemistry and their relation to the travertine deposition. More practically, is there any contamination caused by the tourist activity and how can the influences of climate and human activities on the travertine deposition be distinguished?

This study is significant for two major reasons. Firstly, it is the first major attempt in the World Heritage site to reveal diurnal variations of hydrochemistry under different biological conditions. Secondly, it extends our understanding of contemporary hydrochemical processes in travertine-depositing streams subject to human interference and thus provides more information for protection of the travertines and interpretation of the depositional paleoenvironment.

\section{GENERAL SETTINGS OF THE STUDY AREA}

Huanglong Ravine is located about $360 \mathrm{~km}$ NW of the provincial capital, Chengdu, Sichuan Province, on the southern slopes of the Minshan Mountains that separate the Qinghai Highlands from the Sichuan Basin. Its eleva- 


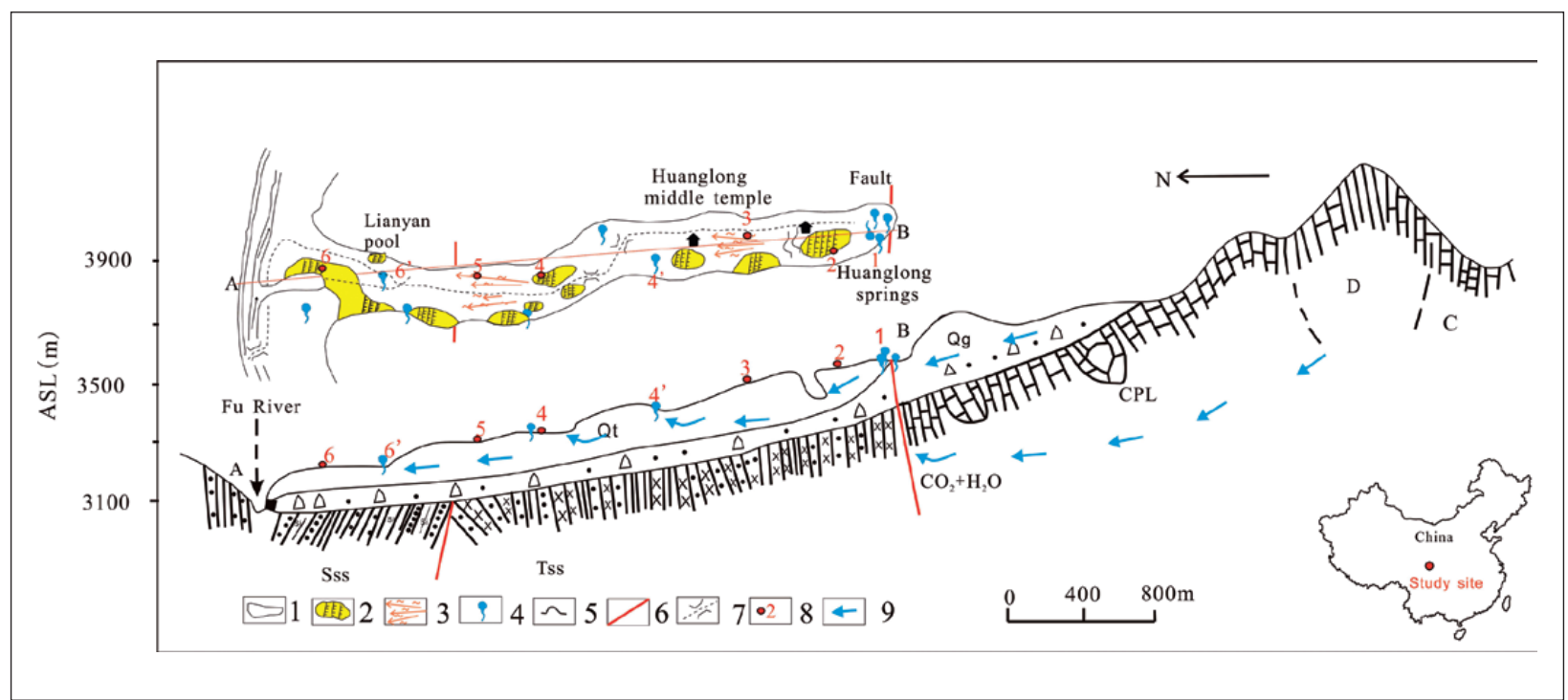

Fig. 1: Plan and geological section of Huanglong Ravine with sampling sites.

1. boundary of the travertine scenery; 2. rimstone dam and pool; 3. travertine shoal; 4. spring; 5. travertine cave; 6. fault; 7. trail; 8. sampling site; 9. flow direction of groundwater.

Qt/Qg-Quaternary travertine/glacial sand and gravel; Tss-Triassic sandstone and slate; CPL-Carboniferous and Permian limestone; C-Carboniferous limestone; D-Devonian slate and limestone; Sss- Silurian slate, intercalated with sandstone.

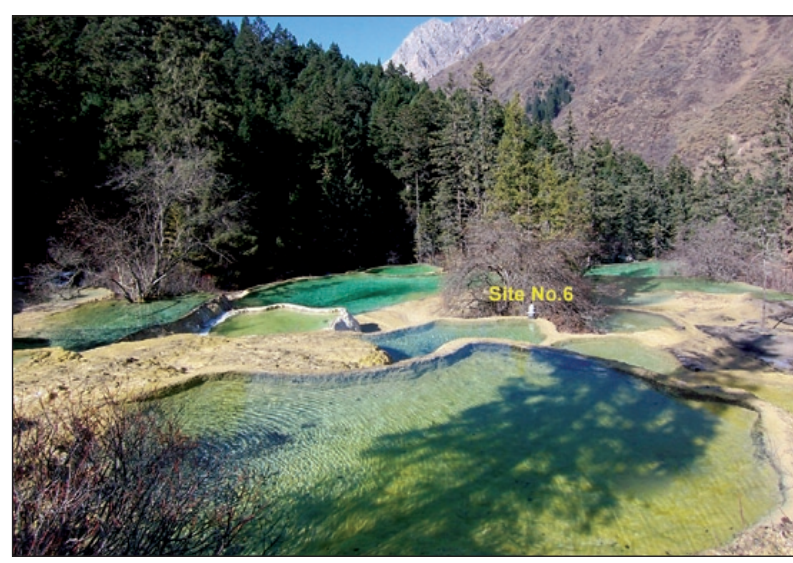

Fig. 2: Travertine rimstone pools at Yingbinchi (Guest-welcoming Ponds) in Huanglong Ravine (with site No. 6 in Fig. 1; Photo: Z. Liu).

tion ranges from 3,100 to 3,600 $\mathrm{m}$ above sea level (asl). The geology consists of Paleozoic carbonate rocks exceeding $4,000 \mathrm{~m}$ in thickness, overlain by about $1,000 \mathrm{~m}$ of Mesozoic clastic rocks plus Cenozoic alluvial gravels, glacial moraines and travertine (Liu et al. 1995). In the Ravine, the travertine deposits have accumulated over a width of $\sim 250 \mathrm{~m}$ for a length of $3.5 \mathrm{~km}$ (Fig. 1), in the form of flowstones with many rimstone dams over one $\mathrm{m}$ in height that impound the stream (Fig. 2). The surfaces of the travertines are covered with bryophytes and cyanobacteria of various colors (Fig. 3).

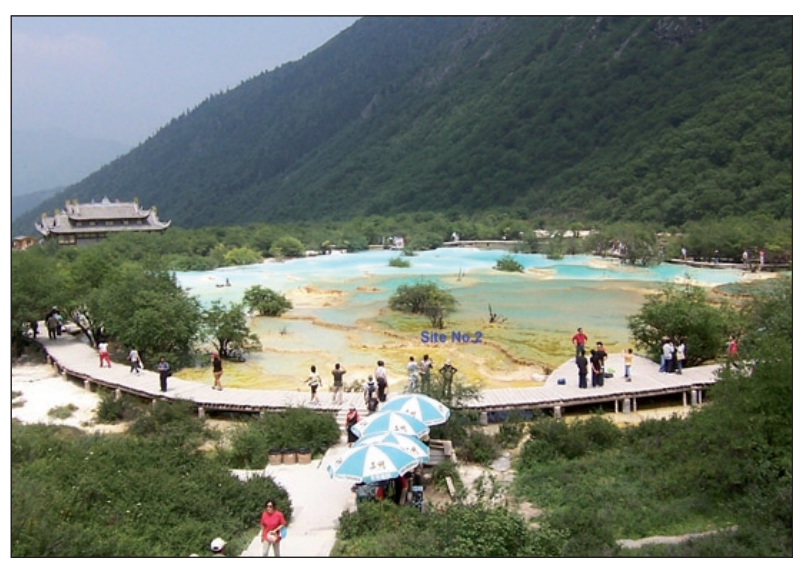

Fig. 3: Travertine rimstone pools at Wucaichi (Multi-colored Ponds) in Huanglong Ravine (with site No. 2 in Fig. 1; Photo: Z. Liu).

The average annual precipitation is $759 \mathrm{~mm}$ and the mean temperature $1.1^{\circ} \mathrm{C}$. Groundwater issues along a fault zone at an altitude of about $3,580 \mathrm{~m}$ asl, with a water temperature about $5^{\circ} \mathrm{C}$ higher than that of annual mean air temperature. The surface stream is a mixture of this groundwater together with glacier and/or snowmelt water from higher mountains (the highest peak, Xuebaoding, is at $5,588 \mathrm{~m}$ asl). There is no travertine deposition in the valley upstream of the point where the groundwater enters the channel. 


\section{METHODS}

\section{MONITORING THE WATER CHEMISTRY; ANALYTICAL CHEMISTRY}

To measure the detailed hydrochemical variations of Huanglong Spring, a Greenspan CTDP 300 multi-channel data logger (Liu et al. 2004, 2007) was installed close to the orifice. Rainfall, water stage, water temperature, $\mathrm{pH}$ and specific conductivity $(\mathrm{SpC})$ of the spring were monitored every $15 \mathrm{~min}$, with resolutions of $0.5 \mathrm{~mm}$, $0.001 \mathrm{~m}, 0.1^{\circ} \mathrm{C}, 0.01 \mathrm{pH}$, and $0.01 \mu \mathrm{S} / \mathrm{cm}$, respectively. The logger was calibrated prior to deployment using $\mathrm{pH}$ $(4,7$ and 10$)$ and conductivity $(1,412 \mu \mathrm{S} / \mathrm{cm})$ standards. According to the technical data sheet the CTDP-300 has an accuracy of $\pm 0.2, \pm 0.1^{\circ} \mathrm{C}, \pm 0.2 \% \mathrm{FS}$ in $\mathrm{pH}$, temperature and $\mathrm{SpC}$ respectively.

To measure detailed hydrochemical variations in the travertine-depositing stream, eight sampling sites (Fig. 1) were chosen downstream along the Huanglong channel. Water temperature, $\mathrm{pH}$ and specific conductivity were measured in-situ daily at the sites, with a handheld water quality meter (WTW 350i) with accuracies of $\pm 0.004 \mathrm{pH}$ unit, $\pm 0.1^{\circ} \mathrm{C}$ and $\pm 0.5 \%$, respectively. In situ titration was used to determine $\left[\mathrm{HCO}_{3}^{-}\right]$and $\left[\mathrm{Ca}^{2+}\right]$ semimonthly by Aquamerck Alkalinity Test and Hardness Test. The resolutions are 6 and $1 \mathrm{mg} / \mathrm{l}$, respectively (Liu et al. 2007).

To understand the general chemistry, waters at the sampling sites were collected monthly by syringes with $0.45 \mu \mathrm{m}$ Minisart filter and analyzed in the State Key Laboratory of Environmental Geochemistry, Institute of Geochemistry of Chinese Academy of Sciences. Concentrations of $\mathrm{K}^{+}, \mathrm{Na}^{+}$and $\mathrm{Mg}^{2+}$ were determined by atomic absorption spectrometry and those of $\mathrm{Cl}^{-}, \mathrm{PO}_{4}^{3-}$ and $\mathrm{SO}_{4}^{2-}$ by ion chromatography.

\section{ESTIMATING $\mathrm{CO}_{2}$ PARTIAL PRESSURE AND THE CALCITE SATURATION INDEX FROM CONTINUOUS RECORDS OF WATER TEMPERATURE, PH AND SPECIFIC CONDUCTIVITY}

In pure limestone areas such as the case in this study, specific conductivity fluctuations in travertine-deposit- ing stream can be attributed solely to $\mathrm{Ca}^{2+}$ and $\mathrm{HCO}_{3}^{-}$ changes by calcite deposition or dissolution (Krawcyzk \& Ford 2006). So, paired $\mathrm{Ca}^{2+}$ (or $\mathrm{HCO}_{3}^{-}$) and conductivity values were correlated and regression was used to establish a time-series of $\mathrm{Ca}^{2+}$ and $\mathrm{HCO}_{3}^{-}$changes.

At Huanglong, these concentrations are linearly related to specific conductivity by the relationships:

$$
\begin{aligned}
& {\left[\mathrm{Ca}^{2+}\right]=0.2426 \mathrm{SpC}-6.517 \mathrm{r}^{2}=0.9991} \\
& {\left[\mathrm{HCO}_{3}^{-}\right]=0.7367 \mathrm{SpC}-24.92 \mathrm{r}^{2}=0.9992}
\end{aligned}
$$

where brackets denote species concentrations in $\mathrm{mg} / \mathrm{L}$ and $\mathrm{SpC}$ is specific conductivity in $\mu \mathrm{s} / \mathrm{cm}$ at $25^{\circ} \mathrm{C}$.

The full hydrochemical data sets, including recorded temperature and $\mathrm{pH}$, calculated $\mathrm{Ca}^{2+}$ and $\mathrm{HCO}_{3}^{-}$ through the relationships above, mean seasonal values of $\mathrm{K}^{+}, \mathrm{Na}^{+}, \mathrm{Mg}^{2+}, \mathrm{Cl}^{-}$and $\mathrm{SO}_{4}^{2-}$, were processed through the program WATSPEC (Wigley 1977), which calculates $\mathrm{CO}_{2}$ partial pressure $\left(\mathrm{pCO}_{2}\right)$ and calcite saturation index $\left(\mathrm{SI}_{C}\right)$ for each record (Liu et al. 2007). $\mathrm{PCO}_{2}$ is calculated from:

$$
\mathrm{pCO}_{2}=\frac{\left(\mathrm{HCO}_{3}^{-}\right)\left(\mathrm{H}^{+}\right)}{\mathrm{K}_{\mathrm{H}} \mathrm{K}_{1}}
$$

where $\mathrm{K}_{\mathrm{H}}$ and $\mathrm{K}_{1}$ are the temperature-dependent Henry's Law and first dissociation constants for $\mathrm{CO}_{2}$ gas in water, respectively.

SIc is calculated from:

$$
\mathrm{SI}_{\mathrm{C}}=\log \left(\frac{\left(\mathrm{Ca}^{2+}\right)\left(\mathrm{CO}_{3}^{2-}\right)}{\mathrm{K}_{\mathrm{C}}}\right)
$$

where activities are denoted by brackets, and $\mathrm{K}_{\mathrm{c}}$ is the temperature dependent equilibrium constant for calcite dissociation. If $\mathrm{SI}_{\mathrm{c}}>0$, water is supersaturated with respect to calcite and may deposit it; if $\mathrm{SI}_{\mathrm{c}}<0$, water is aggressive with respect to calcite and may dissolve it; where $\mathrm{SI}_{c}=0$, dynamic equilibrium is attained. 


\section{RESULTS AND DISCUSSION}

\section{GENERAL HYDROCHEMICAL COMPOSITION OF HUANGLONG SPRING}

Tab. 1 shows the general hydrochemical compositions of Huanglong Spring (sampling site No. 1 in Fig. 1). It is seen that $\mathrm{Ca}^{2+}$ and $\mathrm{Mg}^{2+}$ are the major cations in the waters, with a combined molarity percentage of $>95 \%$ : $\mathrm{HCO}_{3}^{-}$is the major anion with a molarity percentage of $>90 \%$. Thus, the hydrochemical classification of the spring water is simple $\mathrm{HCO}_{3}-\mathrm{Ca}, \mathrm{Mg}$, which reflects the control by the Carboniferous- Permian carbonate bedrock at the site.
The spring water has very high concentrations of calcium and bicarbonate, amounting to more than 250 and $750 \mathrm{mg} / \mathrm{l}$, respectively, and the corresponding $\mathrm{CO}_{2}$ partial pressure is more than $12,500 \mathrm{~Pa}$ (Tab. 1). According to many observations elsewhere in China (Liu \& Yuan 2000), even in the warm and humid tropical and sub-tropical zones, the partial pressure of biological $\mathrm{CO}_{2}$ in soil is no more than $10,000 \mathrm{~Pa}$, and the concentrations of calcium and bicarbonate are typically less than 150 and $450 \mathrm{mg} / \mathrm{l}$, respectively. Pentecost and Zhang (2001) also found that concentrations of dissolved inorganic carbon derived from limestone

Tab. 1: Hydrochemical features of the Huanglong Spring.

\begin{tabular}{|c|c|c|c|c|c|c|c|c|c|c|c|c|}
\hline $\begin{array}{l}\text { Date } \\
\text { (yyyy-mm-dd) }\end{array}$ & $K^{+}$ & $\mathrm{Na}^{+}$ & $\mathrm{Ca}^{2+}$ & $\begin{array}{l}M g^{2+} \\
(m g / l)\end{array}$ & $\mathrm{Cl}^{-}$ & $\mathrm{SO}_{4}^{2-}$ & $\mathrm{HCO}_{3}^{-}$ & $\begin{array}{c}\text { Temp. } \\
\left({ }^{\circ} \mathrm{C}\right)\end{array}$ & $p H$ & $\begin{array}{c}S p C \\
\left(\mu \mathrm{s} / \mathrm{cm}, 25^{\circ} \mathrm{C}\right)\end{array}$ & SIC & $\begin{array}{c}p \mathrm{CO}_{2} \\
(100 \mathrm{~Pa})\end{array}$ \\
\hline 2007-9-3 & 0.43 & 3.79 & 262 & 20.80 & 0.84 & 24.12 & 780 & 6.3 & 6.65 & 1074 & 0.12 & 127.64 \\
\hline 2007-9-18 & 0.41 & 3.66 & 271 & 20.56 & 1.09 & 24.35 & 805 & 6.4 & 6.59 & 1107 & 0.08 & 151.01 \\
\hline 2007-10-7 & 0.42 & 3.71 & 252 & 20.63 & 1.15 & 24.34 & 750 & 6.3 & 6.56 & 1035 & 0.00 & 151.71 \\
\hline 2007-10-24 & 0.41 & 3.67 & 252 & 20.74 & 1.14 & 23.90 & 750 & 6.2 & 6.59 & 1035 & 0.03 & 141.58 \\
\hline 2007-11-7 & 0.43 & 3.65 & 252 & 20.46 & 1.27 & 23.54 & 750 & 6.2 & 6.56 & 1034 & 0.00 & 151.36 \\
\hline 2008-4-29 & 0.38 & 2.48 & 272 & 21.22 & 0.26 & 22.78 & 808 & 6.2 & 6.60 & 1111 & 0.09 & 148.25 \\
\hline $2008-5-13$ & 0.38 & 2.45 & 282 & 21.53 & 0.26 & 22.19 & 839 & 6.2 & 6.56 & 1152 & 0.08 & 168.27 \\
\hline $2008-7-25$ & 0.39 & 2.91 & 276 & 23.48 & 0.15 & 19.31 & 823 & 7.0 & 6.56 & 1130 & 0.08 & 166.34 \\
\hline 2008-8-11 & 0.38 & 2.70 & 272 & 22.48 & 0.17 & 20.20 & 808 & 7.2 & 6.58 & 1111 & 0.09 & 156.31 \\
\hline $2008-8-26$ & 0.35 & 2.56 & 264 & 21.83 & 0.13 & 13.75 & 785 & 7.3 & 6.51 & 1081 & 0.00 & 179.06 \\
\hline 2008-9-11 & 0.34 & 2.57 & 259 & 22.14 & 0.11 & 15.60 & 772 & 7.2 & 6.54 & 1063 & 0.01 & 164.44 \\
\hline 2008-9-26 & 0.35 & 2.85 & 257 & 21.83 & 0.13 & 16.00 & 763 & 7.2 & 6.57 & 1052 & 0.03 & 151.71 \\
\hline 2008-10-2 & 0.34 & 2.78 & 268 & 22.21 & 0.17 & 17.92 & 798 & 7.3 & 6.48 & 1097 & -0.02 & 194.54 \\
\hline 2008-10-7 & 0.34 & 2.52 & 268 & 22.17 & 0.12 & 20.08 & 798 & 7.0 & 6.39 & 1097 & -0.12 & 238.78 \\
\hline $2009-5-4$ & 0.44 & 2.95 & 275 & 21.22 & 1.33 & 29.68 & 819 & 6.5 & 6.48 & 1125 & -0.02 & 198.15 \\
\hline $2009-5-20$ & 0.48 & 3.64 & 279 & 21.84 & 0.85 & 28.47 & 831 & 6.6 & 6.59 & 1141 & 0.10 & 155.96 \\
\hline $2009-6-4$ & 0.79 & 5.47 & 275 & 22.15 & 0.86 & 28.04 & 820 & 6.5 & 6.41 & 1126 & -0.09 & 232.81 \\
\hline 2009-6-18 & 0.71 & 3.42 & 273 & 21.89 & 1.02 & 28.71 & 812 & 6.6 & 6.43 & 1116 & -0.07 & 220.80 \\
\hline $2009-7-2$ & 0.63 & 3.39 & 274 & 21.85 & 2.06 & 28.33 & 814 & 6.5 & 6.61 & 1119 & 0.11 & 145.88 \\
\hline 2009-7-20 & 0.58 & 3.08 & 272 & 22.51 & 1.09 & 27.59 & 810 & 6.6 & 6.54 & 1113 & 0.04 & 170.61 \\
\hline $2009-8-4$ & 1.74 & 3.00 & 270 & 21.43 & 0.99 & 27.99 & 802 & 6.6 & 6.51 & 1103 & 0.00 & 181.55 \\
\hline 2009-8-18 & 0.58 & 2.92 & 271 & 21.89 & 1.50 & 28.71 & 807 & 6.6 & 6.50 & 1109 & -0.01 & 186.64 \\
\hline 2009-9-2 & 0.55 & 2.76 & 275 & 21.14 & 1.52 & 28.14 & 817 & 6.5 & 6.55 & 1123 & 0.05 & 168.27 \\
\hline 2009-9-18 & 0.54 & 2.69 & 272 & 21.22 & 1.28 & 29.45 & 810 & 6.5 & 6.53 & 1114 & 0.03 & 174.98 \\
\hline 2009-9-30 & 0.51 & 2.64 & 271 & 21.05 & 1.42 & 25.39 & 806 & 6.5 & 6.56 & 1108 & 0.05 & 162.55 \\
\hline 2009-10-15 & 0.5 & 2.59 & 272 & 21.00 & 1.03 & 29.52 & 810 & 6.5 & 6.57 & 1114 & 0.07 & 159.59 \\
\hline $2009-10-26$ & 0.52 & 2.58 & 271 & 20.73 & 1.30 & 28.35 & 807 & 6.4 & 6.57 & 1110 & 0.06 & 158.85 \\
\hline 2009-11-5 & 0.53 & 2.68 & 270 & 21.34 & 1.28 & 28.66 & 804 & 6.4 & 6.60 & 1105 & 0.09 & 147.57 \\
\hline 2009-11-15 & 0.56 & 2.79 & 269 & 21.50 & 1.26 & 28.97 & 801 & 6.4 & 6.62 & 1102 & 0.11 & 140.60 \\
\hline
\end{tabular}

Data are not available in winter season (December to March) due to snowing.

Values for $\mathrm{Ca}^{2+}, \mathrm{HCO}_{3}^{-}$, Temp., $\mathrm{pH}$ and $\mathrm{SpC}$ were obtained in situ. 


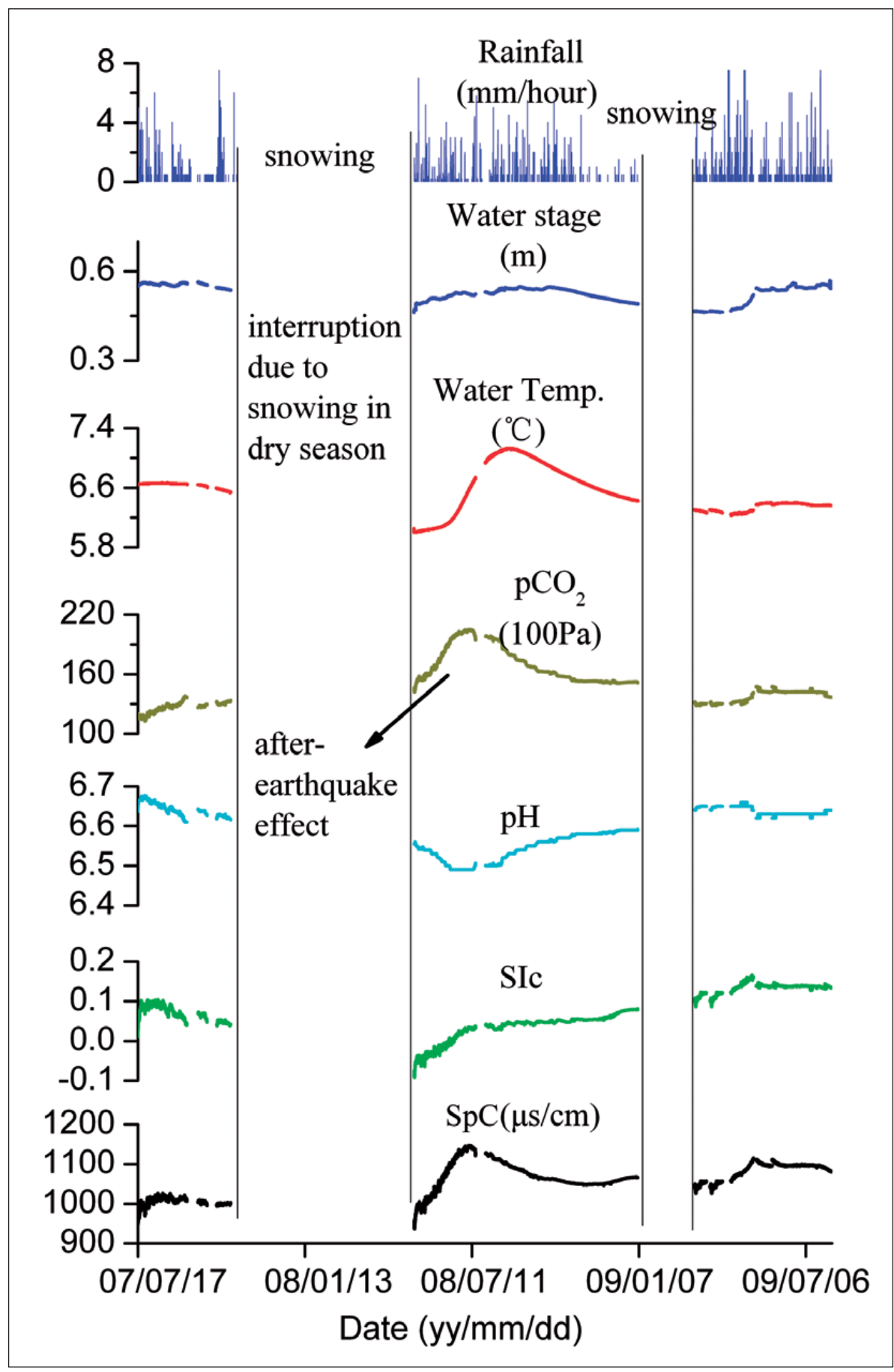

Fig. 4: Long-term hydrochemical variations of the Huanglong Spring. cold for substantial biogenic $\mathrm{CO}_{2}$ production. Therefore, it is likely that endogenic $\mathrm{CO}_{2}$ plays a more important role (Liu et al. 2003). The water at Huanglong Spring is near equilibrium with respect to calcite but slightly undersaturated (Tab. 1).

\section{TEMPORAL \\ HYDROCHEMICAL \\ VARIATIONS AT \\ HUANGLONG SPRING}

Figs. 4 and 5 show the seasonal and diurnal variations at Huanglong Spring respectively. It can be seen that there is neither clear seasonal nor diurnal variation in the hydrochemistry, indicating the high regulating capacity of the system. This is likely an effect of control by an endogenic karst ground water system where all the hydrochemical indexes are relatively stable and less influenced by local climate (Liu et al. 2003; Sun 2008). For example, the remarkable increase in water temperature, $\mathrm{pCO}_{2}, \mathrm{H}^{+}$, and $\mathrm{SpC}$ after May 122008 (Fig. 4) was due to effect of the great earthquake (M 8.0) at 14:30 hours that day at Wenchuan (Sichuan), which induced reactions in the endogenic karst system at Huanglong. This increase lasted about two months after the earthquake, and then the hydrochemistry returned to pre-earthquake values over the course of the next dissolution caused by biological $\mathrm{CO}_{2}$ rarely exceed $10 \mathrm{mmol} / \mathrm{l}$ (usually 2-5 mmol/l). Therefore, the hydrochemistry of Huanglong Spring cannot be explained by biological activity in the soil alone. Moreover, temperature of less than $2^{\circ} \mathrm{C}$ in the spring recharge area is too three months (Fig. 4). This situation contrasts with, e.g., sample epikarst springs in Guangxi and Guizhou, SW China, whose hydrochemistry shows both clear seasonal and diurnal variations controlled by climate variability (Liu et al. 2007). 


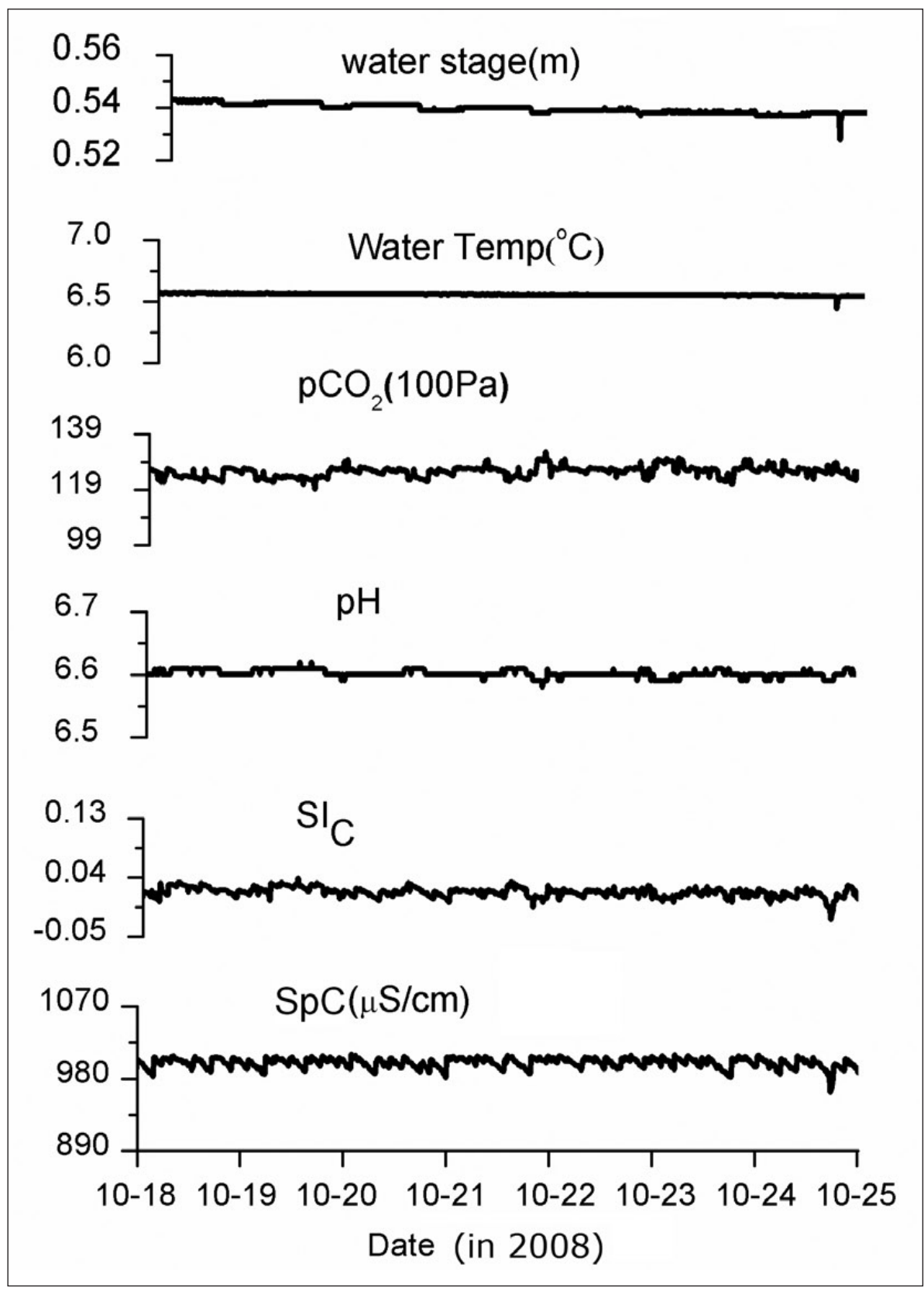

Fig. 5: Diurnal hydrochemical variations of the Huanglong Spring.

SPATIAL AND TEMPORAL HYDROCHEMICAL VARIATIONS OF THE TRAVERTINE-DEPOSITING STREAM

\section{SPATIAL HYDROCHEMICAL VARIATIONS}

Fig. 6 shows the spatial hydrochemical variations of the stream in the rainy season (September 2007) and dry season (November 2007).

As mentioned above, the travertine-depositing spring had very high concentrations of calcium and bi- carbonate due to the very high $\mathrm{CO}_{2}$ partial pressures of the endogenic karst system. However, as the spring water emerged, a large amount of $\mathrm{CO}_{2}$ was released to the atmosphere where $\mathrm{CO}_{2}$ partial pressure was less than $40 \mathrm{~Pa}$. Consequently, as the water flowed downstream from the spring, $\mathrm{pH}$ increased, the water became supersaturated with respect to calcite, and travertine was deposited.

It is seen from Fig. 6 that after about $3.5 \mathrm{~km}$ flow downstream, the $\mathrm{CO}_{2}$ partial pressure of the water has decreased from 14,000 $\mathrm{Pa}$ (at the spring) to $100 \mathrm{~Pa}$, $\mathrm{pH}$ increased from 6.3 to 8.4 , and the calcite saturation index increased from near zero to more than 1.0 . Correspondingly, calcium carbonate was deposited as travertine along the stream bed, and concentrations of $\mathrm{Ca}^{2+}$ and $\mathrm{HCO}_{3}^{-}$in the water decreased from 240 and $750 \mathrm{mg} / \mathrm{l}$ to 100 and $300 \mathrm{mg} / \mathrm{l}$ respectively (Fig. 6).

However, this general pattern of spatial hydrochemical evolution was interrupted by discharge from downstream springs Nos. 4' (Jiexianqiao Spring, Fig. 7) and 6' (Longyan Spring, Fig. 8) along the channel. Increases of $\mathrm{Ca}^{2+}$ and $\mathrm{HCO}_{3}^{-}$at sample sites 4 and 6 was due to the input of these spring waters. It can also be seen from Fig. 6 that rapid release of $\mathrm{CO}_{2}$ from the Huanglong Spring water happened mostly between sampling sites No. 1 and No. 2, which resulted in remarkable increase of $\mathrm{pH}$ and $\mathrm{SI}_{\mathrm{C}}$ and decrease of $\mathrm{HCO}_{3}^{-}$and $\mathrm{Ca}^{2+}$. However, the abnormal decrease of the concentration of $\mathrm{HCO}_{3}^{-}$and $\mathrm{Ca}^{2+}$ at site No. 3 was not the result of travertine deposition but was due to dilution of stream by snow-melt water (Liu et al. 1995), as evidenced by the decrease of SIc at site No. 3 . 


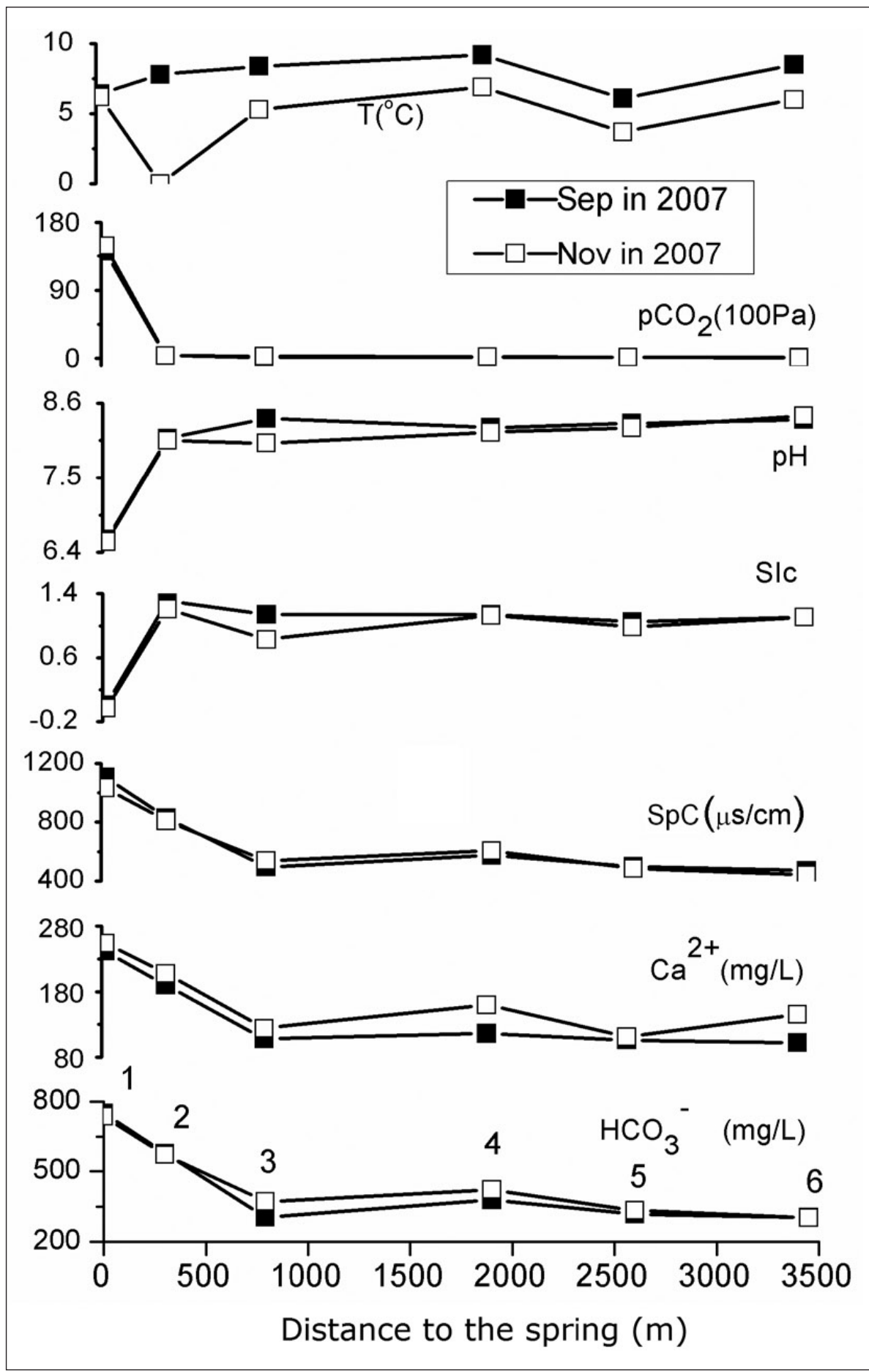

Fig. 6: Spatial hydrochemical variations along the Huanglong Ravine in rainy (September) and dry (November) seasons.

\section{TEMPORAL HYDROCHEMICAL VARIATIONS}

After the spring water emerged, it was changed from a closed system to an open system. Thus, its hydrochemistry experienced not only spatial change, but also remark- able temporal change. Fig. 9 shows the diurnal variations in temperature, $\mathrm{pCO}_{2}, \mathrm{pH}$, SIc and conductivity at site No. 5 (Fig. 9b) and in Lianyan pool (9c). For comparison, the diurnal hydrochemical variation of the source spring over the same time period is also displayed (Fig. 9a). It is seen that all hydrochemical parameters at the downstream sites show distinct diurnal changes, i.e., $\mathrm{pCO}_{2}$ and $\mathrm{SpC}$ were lower and $\mathrm{pH}$ and SIc were higher in daytime than at nighttime, which contrasts to the stable case of the source spring as stated above. The increase of $\mathrm{pH}$ in pools may be caused mainly by the photosynthesis activities of algae, phytoplankton and aquatic plants in the pools, which are using dissolved $\mathrm{CO}_{2}$ for assimilation as soon as sunlight is available. This results in a decreasing concentration of dissolved $\mathrm{CO}_{2}$ in the pools. Since $\mathrm{CO}_{2}$ partly reacts with water and produces free hydrogen it controls $\mathrm{pH}$ values.

In addition to this, free (surplus) $\mathrm{CO}_{2}$ in water also dissolves solid $\mathrm{CaCO}_{3}$ into calcium bicarbonate (Equation 5).

$$
\begin{array}{r}
\mathrm{CaCO}_{3}(\mathrm{~s})+\mathrm{CO}_{2}(\mathrm{aq})+ \\
\mathrm{H}_{2} \mathrm{O}=\mathrm{Ca}^{2+}+2 \mathrm{HCO}_{3}^{-}
\end{array}
$$

However, the dissolution of $\mathrm{CaCO}_{3}$ only lasts until the free $\mathrm{CO}_{2}$ is completely used and equilibrium with the dissolved calcium bicarbonate is reached (calcium carbonate-carbonic acidequilibrium). If the dissolved $\mathrm{CO}_{2}$ is taken from the system, the inverse process occurs to keep the equilibrium, i.e., dissolved calcium bicarbonate precipitates as solid $\mathrm{CaCO}_{3}$ (Equation 6). 


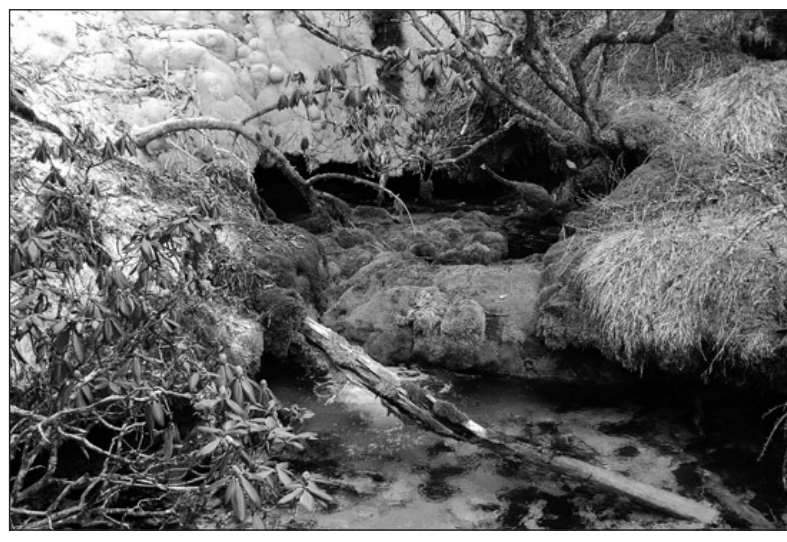

Fig. 7: Jiexianqiao Spring (site No. 4' in Fig. 1; Photo: Z. Liu).

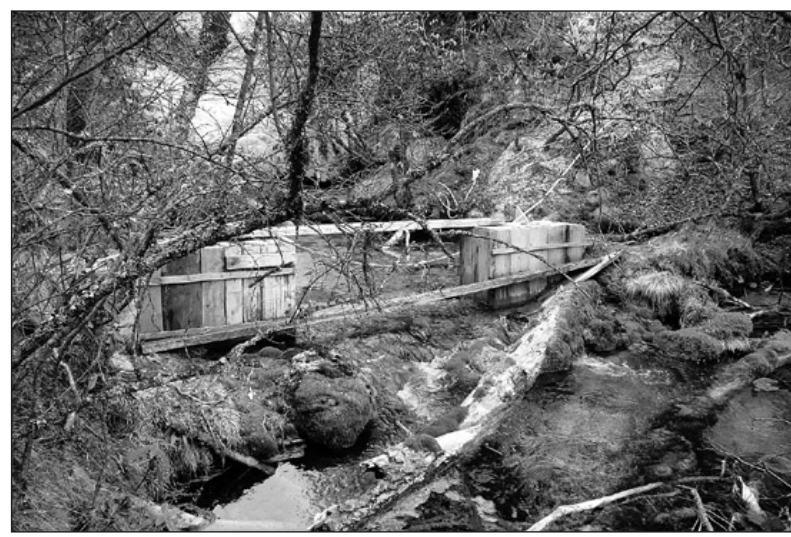

Fig. 8: Longyan Spring (site No. 6' in Fig. 1; Photo: Z. Liu).

$$
\mathrm{Ca}^{2+}+2 \mathrm{HCO}_{3}^{-}=\mathrm{CaCO}_{3} \text { (precipitating) }+\mathrm{CO}_{2}(\mathrm{aq})+\mathrm{H}_{2} \mathrm{O}
$$

Due to the associated extraction of dissolved Ca from the water during this process, it is also called "decalcification" (Equation 6).

When photosynthesis is the main reason for the process it is termed "biological de-calcification" (Winde 2002). Simple increase of water temperature and/or higher $\mathrm{CO}_{2}$ atmospheric partial pressure difference between water and the atmosphere can also reduce the concentration of dissolved carbon dioxide - "physicochemical de-calcification". Triggered by sunlight, photosynthesis started soon after sunrise, accelerating calcite precipitation (Equation 6), as evidenced by the decrease in specific conductivity (Fig. 9). This results in an ongoing decrease of the $\mathrm{CO}_{2}$ concentration in the pools (see $\mathrm{pCO}_{2}$ in Fig. 9c) that simultaneously causes the $\mathrm{pH}$ to rise. Apart from photosynthesis, a rise in water temperature affects the concentration of dissolved $\mathrm{CO}_{2}$ by reducing the solubility of the gas. Thus, increasing water temperature causes decreasing $\mathrm{CO}_{2}$ levels. In the night time, respiration and decreased temperature resulted in higher total carbon dioxide concentrations and hence a gradual decrease in $\mathrm{pH}$, which reduces calcite deposition, and correspondingly the increase of specific conductivity. It was thus inferred that travertine deposition takes place mainly in the daytime, particularly in sunny conditions.

In order to know the quantitative influence of water temperature and aquatic plants on the diurnal variations of hydrochemistry, we chose the Lianyan pool with an abundance of visible aquatic plants (mainly green algae, Fig. 10) for special study. Because $\mathrm{CO}_{2}$ is the key parameter which links temperature, aquatic plants and calcite dissolution/precipitation, we concentrated on the control of temperature and aquatic plants on $\mathrm{pCO}_{2}$, which has been calculated using WATSPEC (Wigley 1977). The temperature control was estimated through the influence of water temperature on Henry's constant (Lu et al. 2006). Maximum $\mathrm{pCO}_{2}$ was $798 \mathrm{~Pa}$, corresponding with the lowest water temperature of $8.0^{\circ} \mathrm{C}$ (constant $\mathrm{K}_{\mathrm{h} 1}=0.059336$ ) and minimum $\mathrm{pCO}_{2}$ was $310 \mathrm{~Pa}$ at the highest temperature of $11.6^{\circ} \mathrm{C}\left(\mathrm{K}_{\mathrm{h} 2}=\right.$ 0.050967). Thus, the maximum multiple of water temperature influence on the $\mathrm{pCO}_{2}$ would be $\mathrm{K}_{\mathrm{h} 1} / \mathrm{K}_{\mathrm{h} 2}=1.13$ and minimum $\mathrm{pCO}_{2}$ would be $798 / 1.13=705 \mathrm{~Pa}$ if water temperature were the only influencing factor. Thus the contribution of water temperature to the diurnal variation of $\mathrm{pCO}_{2}$ is estimated to be $93 \mathrm{~Pa}$ (798-705). However, the combined contribution of water temperature and aquatic plants to diurnal $\mathrm{pCO}_{2}$ variation was $488 \mathrm{~Pa}$ (798-310), so the influence of temperature alone was $(93 / 488) \times 100 \%=19 \%$, and that of photosynthesis was $81 \%(100 \%-19 \%)$.

Travertine shoals (flowstones) are one of the characteristic morphologies in Huanglong Ravine (e.g., the Jinshapudi Travertine Shoal at sampling site No. 5, Fig. 11, extends for several hundred meters, possibly the largest travertine shoal in the world). It is different from the morphologies at Plitvice National Park, Croatia, where calcite deposition is restricted to the lake bottoms formation of lake marl) and to the tufa dams (Emeis et al. 1987). Sampling site No. 5 at the lowest part of Jinshapudi Travertine Shoal had less visible aquatic plants than at the Lianyan pool with its flourishing plants (Fig. 10). Using the same method as above, we found that water temperature was the key factor (> 95\%) controlling diurnal hydrochemical variations at sampling site No. 5 .

\section{SPATIAL VARIATIONS OF CONCENTRATIONS OF PHOSPHATE IN TOURISM OFF-SEASON AND MIDSEASON: INFLUENCE OF HUMAN ACTIVITY}

Fig. 12 shows the spatial variations of the concentration of phosphate in the water samples taken down Huanglong Ravine. Concentrations in Huanglong Spring 

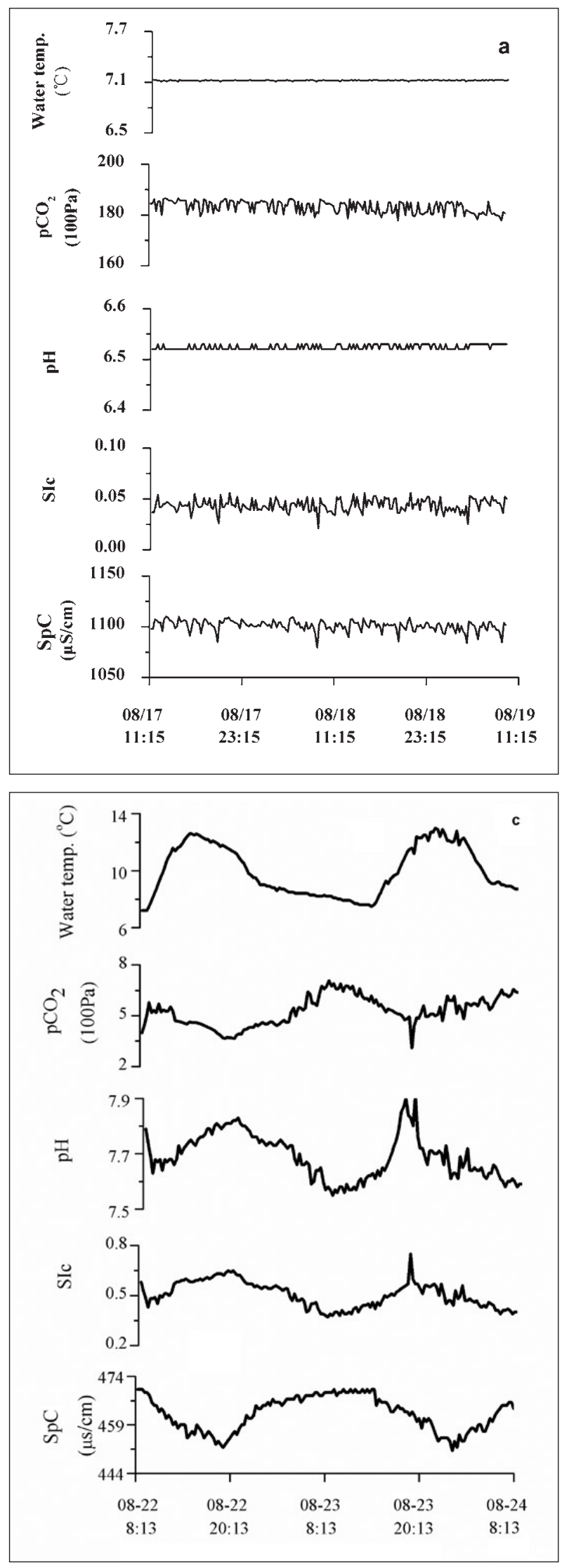

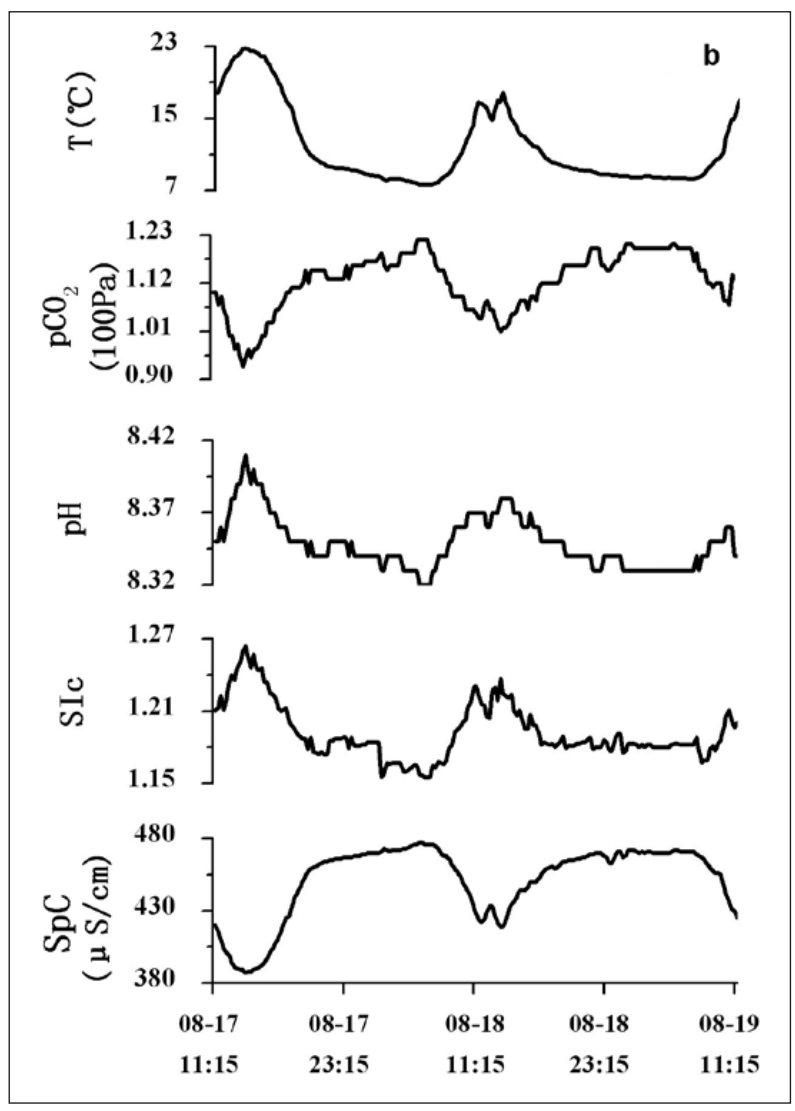

Fig. 9: Diurnal hydrochemical variations of source spring (a), the site No. 5 (b) and the Lianyan pool (c).

(sampling site No. 1) and the surface snow-melt water were taken for the background values, and the measurements at the other sites in April 2008 and September 2007 represented tourism off-season and midseason respectively.

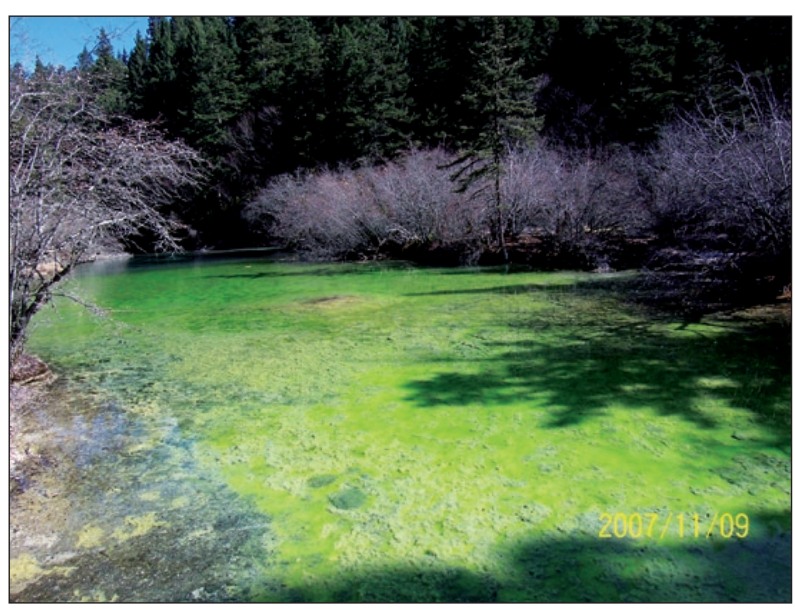

Fig. 10: Lianyan pool with flourishing aquatic plants development (mainly green algae; Photo: Z. Liu). 


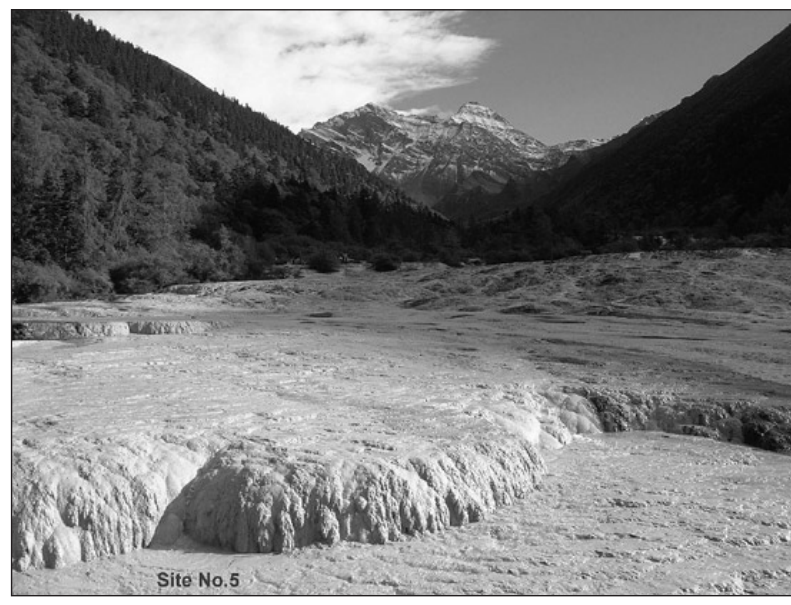

Fig. 11: Travertine shoal at Jinshapudi with quick flow and less aquatic plants (with site No. 5 in Fig. 1; Photo: Z. Liu).

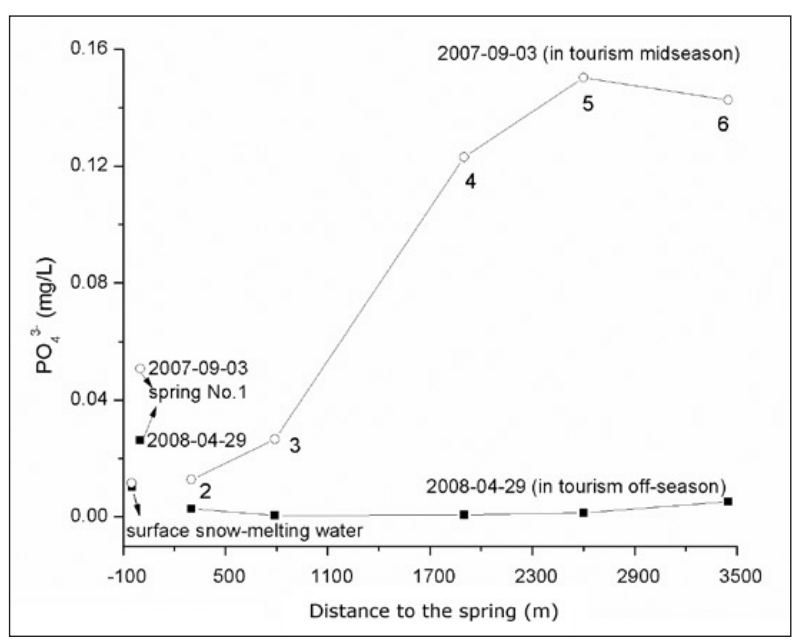

Fig. 12: Spatial variations in concentrations of phosphate along the Huanglong Valley: comparison between the tourism off-season and midseason.

It can be seen from Fig. 12 that there was little variation along the ravine in the tourism off-season (April), with all values close to the background and even some decrease at site No. 2 that was possibly due to the utilization of phosphate by aquatic plants. However, the concentration of phosphate increased abruptly (to about five times the background) from sampling site No. 4 downstream in the tourism midseason (September 2007), indicating the existence of pollution. The values at sampling sites 2 and 3 were between surface snow-melt and Huanglong Spring water, exhibiting mixing of backgrounds only. It was thus inferred that the entrance of the phosphate pollution to the stream was between site No. 3 and site No. 4; from a field survey, it was found that it is very likely due to a tourist restaurant (with toilets behind, Fig. 13) situated between sites 3 and 4 .

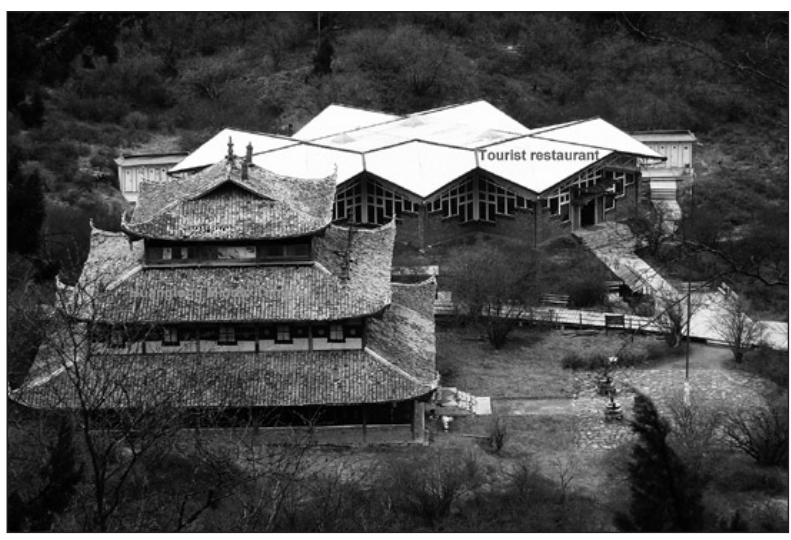

Fig. 13: The tourist restaurant beside the Huanglong Middle Temple, possibly the source of phosphate pollution of the stream water in the ravine (Photo: $Z$. Liu).

According to Drysdale et al. (2002), deposition of calcite will be restrained if the concentration of phosphate is more than $1 \mu \mathrm{mol} / \mathrm{L}$ (about $0.095 \mathrm{mg} / \mathrm{L}$ ). Michaelis et al. (1984) also have found that anthropogenic pollution, e.g., pollution by phosphate, can inhibit calcite deposition. As a consequence the decreases in travertine deposition in the middle- to downstream reaches of Huanglong that have happened recently (see Guo et al.

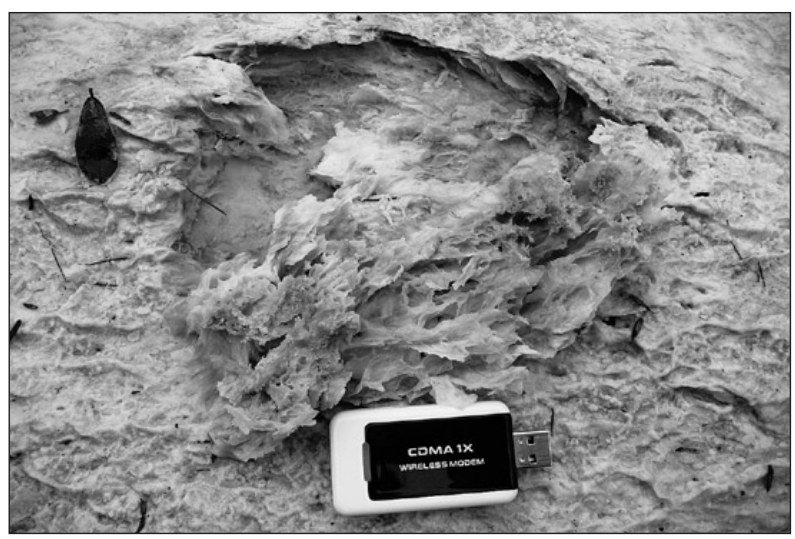

Fig. 14: Prolific diatom mats (mainly Cymbella sp) developed on the Jinshapudi travertine shoal (Photo: Z. Liu).

2002; Xu \& Jiang 2007) may be related to the increase of the phosphate concentration caused by increased tourism activities, especially since Huanglong was placed on the UNESCO World Heritage list in 1992.

Phosphate pollution could also be one of the reasons for the accelerated propagation of diatoms (mainly Cymbella spp., Fig. 14), which is bad for the protection of the travertine landforms. Work by Lu et al. (2000) at this site has shown that thin sections of travertine covered by algae at the bottom of pools have $40 \%$ less $\mathrm{CaCO}_{3}$ pre- 
cipitation than those not covered by algae, and that calcite surfaces with diatoms adhered to them show signs of etching, suggesting that dissolution may be aided by their activity. In addition, the accelerated propagation of diatom cover has changed the color of travertine in some parts of the Ravine from golden yellow to white or even black (Fig. 11), which has diminished the scenic appeal of this World Natural Heritage site.

\section{CONCLUSIONS}

By examining the spatial and temporal variations of the hydrochemistry in the travertine-depositing stream at Huanglong Ravine, Sichuan, SW China, it was found that the deposition of travertine was due to great amounts of $\mathrm{CO}_{2}$ degassing from the water, decreasing $\mathrm{pCO}_{2}$ and conductivity, and increasing $\mathrm{pH}$ and SIc downstream from the source spring. However, dilution or increased concentration is caused by addition of snow-melt water or inputs from other springs interrupted the regular spatial evolution of the hydrochemistry down the Ravine. The chemistry of the Huanglong Spring was stable on the diurnal time scale though it was changed by the great Wenchuan earthquake of May 12 2008. In contrast, in spring-fed pools downstream, $\mathrm{pCO}_{2}$ and $\mathrm{SpC}$ were lower, and $\mathrm{pH}$ and SIc were higher in daytime than at nighttime, which indicates that the deposition of travertine was faster in daytime. It was shown that this was caused by the combined effects of higher water temperature and greater aquatic algae photosynthesis during daytime.

Finally, it was found that the phosphate concentration in the stream water increased remarkably downstream in the tourism midseason in the Ravine, indicating water pollution due to tourism activities. The increase of phosphate concentration may be one of the reasons for the decrease in travertine deposition rates and accelerated propagation of diatom cover during the past two decades, which needs to be given more comprehensive study and taken care of in future for the protection of this world famous travertine landscape.

\section{ACKNOWLEDGEMENTS}

This work was supported by the Hundred Talents Program of Chinese Academy of Sciences, and National Natural Science Foundation of China (Grant No. 40872168). Special thanks are given to Tian Youping, Liu Xiangling, Liu Yan and Zhao Min for their helps in the field work.
We are also indebted to Derek Ford, Ognjen Bonacci and another anonymous reviewer and the editor Nico Goldscheider for their valuable comments and suggestions for revising the manuscript.

\section{REFERENCES}

Dreybrodt, W., Buhmann, D., Michaelis, J. \& E. Usdoswski, 1992: Geochemically controlled calcite precipitation by $\mathrm{CO}_{2}$ outgassing: Field measurements of precipitation rates to theoretical predictions.Chem. Geol., 97, 287-296.

Dreybrodt, W., Eisenlohr, L., Madry, B. \& S. Ringer, 1997: Precipitation kinetics of calcite in the system $\mathrm{CaCO}_{3}{ }^{-} \mathrm{H}_{2} \mathrm{O}^{-} \mathrm{CO}_{2}$ : The conversion to $\mathrm{CO}_{2}$ by the slow process $\mathrm{H}^{+}+\mathrm{HCO}_{3}{ }^{-} \rightarrow \mathrm{CO}_{2}+\mathrm{H}_{2} \mathrm{O}$ as a rate limiting step.- Geochim. Cosmochim. Acta, 61, 3897-3904.
Drysdale, R., Taylor, M. \& C. Ihlenfeld, 2002: Factors controlling the chemical evolution of travertine-depositing rivers of the Barkely karst, north Australia.- Hydrological Processes, 16, 2941-2962.

Drysdale, R., Lucas, S. \& K. Carthew, 2003: The influence of diurnal temperatures on the hydrochemistry of a tufa-depositing stream.- Hydrological Processes, 17, 3421-3441. 
Emeis, K.C., Richnow, H.H. \& S. Kempe, 1987: Travertine formation in Plitvice National Park, Yugoslavia: chemical versus biological control.- Sedimentology, 34, 595-609.

Ford, D.C. \& P.W. Williams, 2007: Karst Hydrogeology and Geomorphology.- Wiley, pp. 562, London.

Ford, T.D. \& H. Pedley, 1996: A review of tufa and travertine deposits of the world.- Earth-Science Reviews, 41, 117-175.

Guo, J., Peng, D. \& J. Yang, 2002: Research of water circulation and the travertine formation causes of Huanglong in Songpan county.- Sichuan Geologica Acta, 22, 21-26 (in Chinese with English abstract).

Herman, J.S. \& M. Lorah, 1987: $\mathrm{CO}_{2}$ outgassing and calcite precipitation in Falling Spring Creek, Virginia, USA.- Chem. Geol., 62, 251-262.

Krawczyk, W.E. \& D.C. Ford, 2006: Correlating specific conductivity with total hardness in limestone and dolomite karst waters.- Earth Surface Processes and Landforms, 31, 221-234.

Liu, Z., Svensson, U., Dreybrodt, W., Yuan, D. \& D. Buhmann, 1995: Hydrodynamic control of inorganic calcite precipitation in Huanglong Ravine, China: Field measurements and theoretical prediction of deposition rates.- Geochimica et Cosmochimica Acta, 59, 3087-3097.

Liu, Z. \& D. Yuan, 2000: Features of geochemical variations in typical epikarst systems of China and their environmental significances.-Geol. Rev., 46, 324327 (in Chinese with English abstract).

Liu, Z., Yuan, D., He, S., Cao, J., You, S., Dreybrodt, W., Svensson, U., Yoshimura, K. \& R. Drysdale, 2003: Origin and forming mechanisms of travertine at Huanglong Ravine of Sichuan.- Geochimica, 32, 1-10 (in Chinese with English abstract).

Liu, Z., Groves, C., Yuan, D. \& J. Meiman, 2004: South China karst aquifer storm-scale hydrogeochemistry.- Ground Water, 42, 491-499.

Liu, Z., Li, Q., Sun, H. \& J. Wang, 2007: Season, diurnal and storm-scale hydrochemical variations of typical epikarst spring in subtropical karst areas of SW China: soil $\mathrm{CO} 2$ and dilution effects.- Journal of Hydrology, 337, 207-223.

Lu, B., Liu, Z., Liao, C. \& H. Sun, 2006: The influence of aquatic plants on diurnal variations of hydrochemistry in karst system-A case in the Guilin Karst Experimental Site.- Carsol. Sinica, 25, 335-340 (in Chinese with English abstract).

Lu, G. \& X. Li, 1992: A study on cold-water travertine surface depositional landforms in Huanglong Scenic Sport, Sichuan province.- Journal of Chengdu College of Geology, 19, 55-64 (in Chinese with English abstract).
Lu, G., 1994: Hydrogeochemical research of cold-water travertine in Huanglong-Jiuzhai scenic spots, Sichuan province.- J. Mineral Petrol., 14, 71-78 (in Chinese with English abstract).

Lu, G., Zheng, C., Donahoea, R.J. \& W. Berry Lyonsa, 2000: Controlling processes in a $\mathrm{CaCO} 3$ precipitating stream in Huanglong Natural Scenic District, Sichuan, China.- Journal of Hydrology, 23, 34-54.

Michaelis, J., Usdowski, E. \& G. Menschel, 1984: Kinetische Faktoren der $\mathrm{CaCO}_{3}$-Abscheidung und der Fraktionierung von ${ }^{12} \mathrm{C}$ und ${ }^{13} \mathrm{C}$.- Wasser. Abwasser. Forsch., 17, 31-36.

Pedley, H.M., 2000: Ambient temperature freshwater microbial tufas.- In: Riding, R. E. \& S. M. Awramik (Eds.) Microbial Sediments. Springer-Verlag, pp. 179-186, Berlin.

Pentecost, A., 1995: The Quaternary travertine deposits of Europe and Asia Minor.- Quaternary Science Reviews, 14, 1005-1028.

Pentecost, A., 1998: The significance of calcite formation by algae in a moss-dominated travertine from Matlock Bath, England.- Archiv für Hydrobiologie, 143, 487-509.

Pentecost, A. \& Z. Zhang, 2001: A review of Chinese tufas.- Cave and Karst Science, 28, 15-28.

Plenkovic-Moraj, A., Horvatincic, N. \& B. Primc-Habdija, 2002: Periphyton and its role in tufa deposition in karstic waters (Plitvice Lakes, Croatia).- Biologia, 57, 423-431.

Sun, H., 2008: Study on the climatic implication of proxies in travertine and their controlling mechanisms: a case at Baishuitai, Yunnan, China.- PhD thesis, Chinese Academy of Geological Sciences, Beijing, pp. 171.

Wigley, T., 1977: WATSPEC--a computer program for determining the equilibrium of aqueous solutions.Br. Geomorphol. Res. Group Tech. Bull., 20, 1-40.

Winde, F., 2002: Uranium contamination of fluvial systems-mechanisms and processes, Germany and Australia.- Cuadernos de Investiacion Geografica, $28,75-100$.

Xu, L. \& Z. Jiang, 2007: Evaluation to the deposition rate of Huanglong travertine by calcium ion equilibrium.- Carsol. Sinica, 26, 132-136 (in Chinese with English abstract). 